\title{
TRUST AS A CONTEXT FOR KNOWLEDGE FLOWS IN CO-OPETITION
}

\author{
Author: Marcin Komańda
}

Originally published in: "Manager" 2011, no. 14, p. 139-151.

Original URL (full text available): http://www.manager.unibuc.ro/images/1413.pdf

\begin{abstract}
Market circumstances related to changes of business environment resulted in the need to find new ways to engage in competitive struggle by companies. This has led to the emergence of cases of establishing cooperation between competitors, the so-called co-opetition. Such cooperation is consistent with the network approach, and one of its key problems are flows of knowledge within it. The aim of this paper is therefore an attempt to establish, basing on critical analysis of literature, theoretical framework of conditions for forming a frame of basic conditions for exchange of knowledge in the case of co-operation of competitors.
\end{abstract}

Key words: co-opetition, knowledge, trust, network, value. 